\title{
Prototheca zopfii genotype 2 disseminated infection in a dog with neurological signs
}

\section{Luciana Sonne $^{1 *}$ Eduardo Conceição de Oliveira $^{2}$ Fernando Froner Argenta $^{1}$ Rafael Souza Monteggia $^{3}$ Laerte Ferreiro $^{4}$ Uwe Rösler $^{5}$ Olivia Kershaw ${ }^{6}$ David Driemeier ${ }^{1}$}

${ }^{1}$ Setor de Patologia Veterinária, Faculdade de Veterinária, Universidade Federal do Rio Grande do Sul (UFRGS), Av. Bento Gonçalves, 9090, 91540-000, Porto Alegre, RS, Brasil. E-mail: lusonne@yahoo.com.br. "Corresponding author.

${ }^{2}$ Laboratório de Patologia Veterinária, Universidade de Caxias do Sul (UCS), Caxias do Sul, RS, Brasil.

${ }^{3}$ Veterinário autônomo, Porto Alegre, RS, Brasil.

${ }^{4}$ Setor de Micologia, Faculdade de Veterinária, Universidade Federal do Rio Grande do Sul (UFRGS), Porto Alegre, RS, Brasil.

${ }^{5}$ Institute for Animal and Environmental Hygiene, Center for Infection Medicine, Freie Universität Berlin, Berlin, Germany.

${ }^{6}$ Department of Veterinary Pathology, Freie Universität Berlin, Berlin, Germany.

ABSTRACT: Prototheca zopfii is an alga that can cause disease in animals and humans. Here, we reported a case of systemic protothecosis in a 2-year-old female Boxer. The animal exhibited tetraparesis and vertical nystagmus. It died two weeks after the onset of clinical signs and was necropsied. At gross examination, whitish areas were identified in the heart. Oval or round structures were observed by microscopic examination, some of which formed morula-like structures compatible with algae in the heart, skeletal muscle, and brain. Growth of Prototheca sp. was observed in the heart after culture at $37^{\circ} \mathrm{C}$ on Sabouraud agar medium with chloramphenicol. Immunohistochemical analysis of the heart and brain using an anti-Prototheca zopfii polyclonal antibody yielded positive results. Genotyping of the cultured agent from brain and heart samples was performed by restriction fragment length polymorphism of a specific $18 S$ rDNA fragment. P. zopfii genotype 2 was reported to be the cause of disseminated protothecosis in this dog with manifestation in the brain, heart, and skeletal muscle.

Key words: canine, disseminated protothecosis, Prototheca zopfii genotype 2.

Infecção por Prototheca zopfii genótipo 2 disseminada em um cão com sinais neurológicos

RESUMO: A prototecose é uma infecção causada por algas, causadora de doenças em animais e seres humanos. O presente trabalho tem por objetivo relatar um caso de prototecose sistêmica em um canino fêmea, da raça Boxer de dois anos de idade. O animal apresentava tetraparesia e nistagmo vertical. O animal morreu duas semanas após o início dos sinais clínicos e foi realizado o exame de necropsia. Os achados macroscópicos se caracterizavam principalmente por áreas esbranquiçadas no miocárdio. Na histologia observou-se estruturas ovais ou redondas, algumas apresentando estruturas como mórulas compativeis com Prototheca no coração, músculo esquelético e encéfalo. No cultivo do miocárdio em meio Agar Sabouraud com Chloramphenicol a $37^{\circ} \mathrm{C}$ foi observado o crescimento de Prototheca sp. No teste imunohistoquímico do coração, cérebro e cerebelo com anticorpo policlonal anti-P. zopffi, foi observada marcação positiva. Teste de PCR a partir da cultura do agente usando uma sequência de $18 \mathrm{~S}$ rDNA foi realizado para a tipificação do genótipo. P. zopfii genótipo 2 foi encontrado como causa de prototecose disseminada no encéfalo, coração e músculo esquelético nesse cão.

Palavras-chave: canino, prototecose, Prototheca zopfii genótipo 2.

Protothecosis is caused by saprophytic achlorophyllous algae of the genus Prototheca, which are closely related to Chlorella green algae (DILLBERGER et al., 1988; SIQUEIRA et al., 2008; PRESSLER, 2012). Prototheca spp. are spherical to oval in shape and 1.3 to $13.4 \mu \mathrm{m}$ in diameter and 1.3 to $16.1 \mu \mathrm{m}$ in length (HOLLINGSWORTH, 2000; PRESSLER, 2012). The alga is surrounded by a hyaline cell wall of approximately $1 \mu \mathrm{m}$. Scattered sporangia containing two to four endospores with well-evident nuclei may also be observed (SALVADORI et al., 2008). Reproduction occurs by endosporulation, resulting in 2 to 20 or more endospores (HOLLINGSWORTH, 2000). This alga can be detected in both seawater and freshwater, soil, trees, and human and animal feces (DILLBERGER 
et al., 1988). Infection is acquired through ingestion or contact with non-intact skin or mucous membranes (STENNER et al., 2007; PRESSLER, 2012).

Protothecosis has been reported in humans (CARNEIRO et al., 2007) and animals, including bovines (ROESLER et al., 2003), caprines (MACEDO et al., 2008), canines (COOCK et al., 1984; STENNER et al., 2007; SALVADORI et al., 2008; RIBEIRO et al., 2009) and felines (DILLBERGER et al., 1988; HUTH et al., 2015), and is caused by multiple species: P. ulmea, P. stagnora, P. blaschkeae, P. zopfii, and P. wickerhamii. The last two are considered pathogenic to dogs (TSUJI et al., 2006; SIQUEIRA et al., 2008). Although, infection in humans, cats, and dogs typically presents as cutaneous lesions (MACARTNEY et al., 1988; GINEL et al., 1997; PÉREZ et al., 1997; HOSAKA \& HOSAKA, 2004), systemic infection has also been reported in humans (LASS-FLÖRL \& MAYR, 2007) and in dogs (TSUJI et al., 2006). In addition, P. zopfii and $P$. wickerhamii can cause disseminated infection in dogs that mainly presents ophthalmologic and gastrointestinal signs (SIQUEIRA et al., 2008). The most frequent clinical signs in dogs are hematochezia or melena (PRESSLER, 2012), and the type and severity of clinical signs of the disseminated form are related to the area infected (HOLLINGSWORTH, 2000). Involvement of the central nervous system (CNS) is reported in $40 \%$ of infected dogs, with clinical signs that include depression, ataxia, walking in circles, incoordination, and paresis (PRESSLER, 2012). Moreover, systemic protothecosis has been reported to cause blindness and deafness in dogs (COOCK et al., 1984).

A 2-year-old female Boxer was submitted to the Setor de Patologia da Universidade Federal do Rio Grande do Sul for necropsy. Apathy, anorexia, and vomiting were listed in the clinical record. The animal had also exhibited acute locomotor incapacity. Neurological examination had revealed severe tetraparesis, vertical nystagmus, and normal reflexes in all four limbs. Hematological and biochemical (urea, creatinine, ALT and AST) examinations and tests for hemocytozoan detection were performed. Results of for the former were within normal ranges, and the latter were negative. Cerebrospinal fluid (CSF) was collected, and serum glucose was measured. The CSF exhibited yellowish coloration and contained $51.7 \mathrm{mg} \mathrm{dL}^{-1}$ glucose (Reference value (RV): $60-110 \mathrm{U} \mathrm{L}^{-1}$ ), $0.45 \mathrm{~g} \mathrm{dL}^{-1}$ albumin (RV: 0.075 $0.276 \mathrm{~g} \mathrm{dL}^{-1}$ ), increased total protein (TP $4.60 \mathrm{~g} \mathrm{dL}^{-1}$, $\left.\mathrm{RV}: 0.18-0.440 \mathrm{~g} \mathrm{dL}^{-1}\right)$, and pleocytosis $\left(3,800 \mathrm{~mm}^{-3}\right.$, $\mathrm{RV}:<1,500 \mathrm{~mm}^{-3}$ ) with a predominance of eosinophils
(59\%). The CSF findings in this case are suggestive of an infection. After 2 days, the clinical signs of the animal worsened, with the emergence of opisthotonus and difficulty to swallow. The dog was treated with dexamethasone and doxycycline for 1 day, but her clinical condition worsened, and the animal died. Overall, the clinical course was two weeks in duration. At necropsy, gross examination revealed whitish areas within the myocardium (Figure 1A) and a pale liver with accentuation of the lobular pattern. Hyperemia and purulent secretion were observed in one tonsil. No other gross lesions were observed; in particular, there were no alterations in the skin or intestines. The heart, lungs, liver, cerebral cortex, cerebellum, spinal cord, skeletal muscle, pancreas, thymus, small and large intestines, mesenteric lymph nodes, stomach, kidney, urinary bladder, spleen, and tonsils were collected. The organs were fixed in $10 \%$ buffered formalin solution, processed according to routine histological techniques, and stained with hematoxylin and eosin, Grocott's Methenamine Silver (GMS), and Periodic Acid Schiff (PAS). Heart fragments (stored at $4^{\circ} \mathrm{C}$ ) and CSF were subjected to fungal culture. Microscopic examination of the myocardium (Figure 1B), skeletal muscle, cerebral cortex, and cerebellum revealed the presence of several round or oval encapsulated structures. Some intralesional infectious organisms exhibited internal septa that formed morula-like structures, consistent with algal organisms. Mild granulomatous inflammation, consisting mainly of macrophages, lymphocytes and plasma cells, was observed in these organs. Necrotic areas were reported in the myocardium. The intralesional infectious organisms in these tissues stained positively for GMS and PAS (Figure 1C). The tonsil contained a neutrophilic infiltrate and fibrin deposition as well intralesional bacteria; however, structures compatible with algal organisms were not observed. Fungal culture was performed on Sabouraud agar with chloramphenicol at $37^{\circ} \mathrm{C}$. Growth of yeast-like, moist, smooth, white to cream colonies was observed after 48 hours of incubation. Direct microscopic examination revealed the presence of globular and hyaline cells. Culture using trehalose-containing medium was performed as an additional biochemical test and yielded negative results, which is expected for $P$. zopfii cultures.

To further characterize the intralesional algae, sections of the heart and brain were incubated in $10 \mathrm{mM}$ citrate buffer at $\mathrm{pH} 6.0$ and heated in a microwave for 20 minutes. After this pretreatment, the sections were treated with normal goat serum diluted 1:5 in phosphate-buffered saline (PBS) 


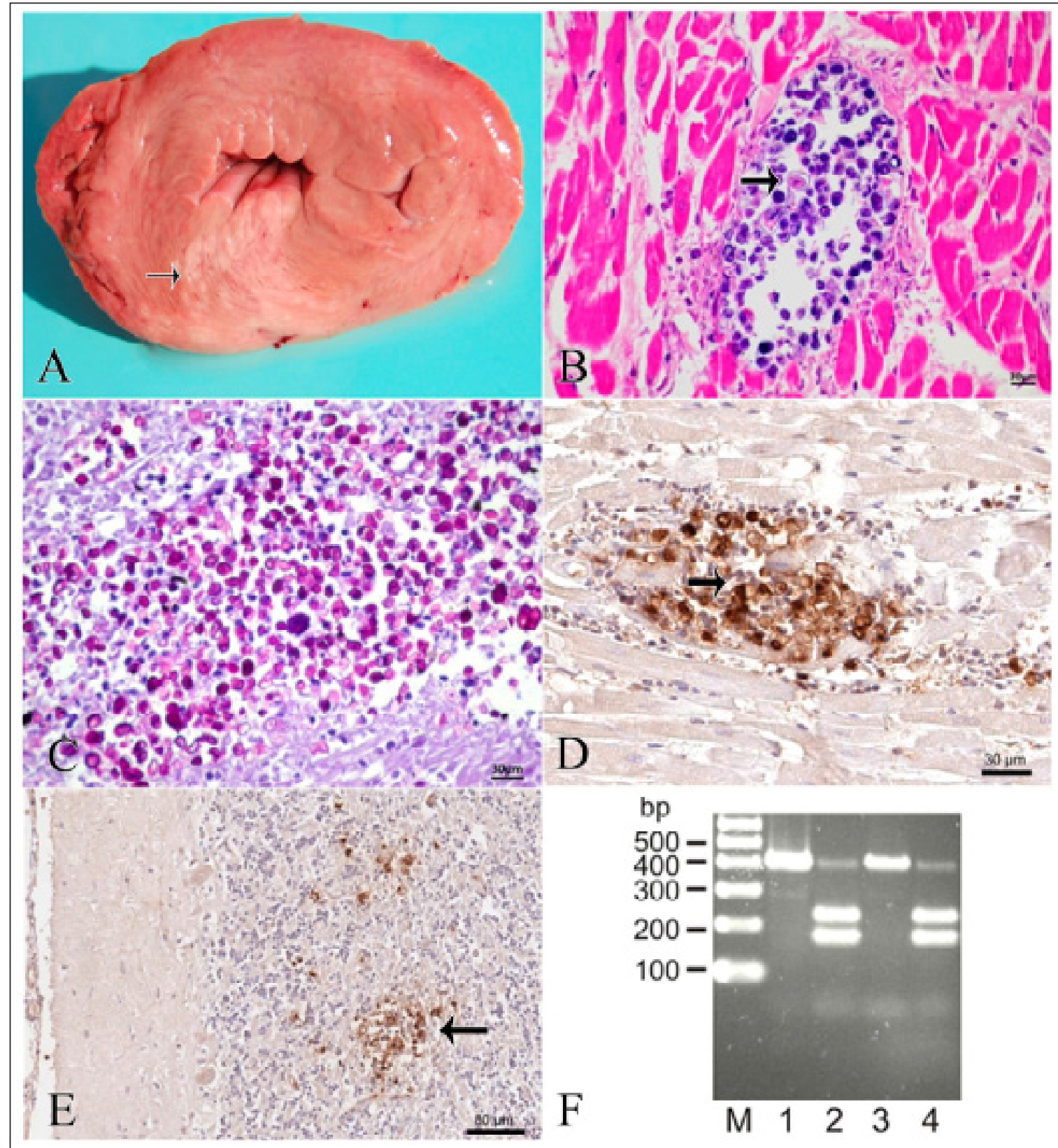

Figure 1 - A 2-year-old Boxer dog with disseminated protothecosis. Gross findings of the heart (A), histopathological findings within the myocardium (B) and cerebellum (C), immunhistochemistry for the detection of Prototheca zopfii antigen in the myocardium (D) and cerebellum (E) as well as results of the molecular analysis (F). A. Whitish areas in the heart of a Boxer dog with protothecosis (arrow). B. Numerous sporangia suggestive of the presence of algae (arrow) in the myocardium. Hematoxylin and eosin. Bar $=30 \mu \mathrm{m}$. C. Oval organisms characteristic of Prototheca in the cerebellum in a dog. PAS reaction. Bar $=30 \mu \mathrm{m}$. D. Detection of numerous algal organisms immunopositive for Prototheca zopfi-antigen (arrow) within an area of mild granulomatous myocarditis. Immunohistochemistry (IHC). Bar $=30 \mu \mathrm{m}$. E. Cerebellum with the presence of numerous algal organisms immunopositive for Prototheca zopfi-antigen (arrow) within an area of mild granulomatous encephalitis. IHC. Bar $=80 \mu \mathrm{m}$. F. Restriction fragment length polymorphism of a specific $18 \mathrm{~S}$ rDNA fragment (405bp length) after incubation with SmaI. M, marker; lane 1- P. zopfii Genotype 1 type strain SAG 2063; lane 2 - P. zopfii Genotype 2 type strain SAG 2021; lane 3 - P. blaschkeae type strain SAG 2064; lane 4 - P. zopfii isolated from the affected dog.

Ciência Rural, v.47, n.8, 2017. 
containing $2 \%$ bovine serum albumin (BSA) for 30 minutes at room temperature. The slides were then incubated at $4{ }^{\circ} \mathrm{C}$ overnight with polyclonal rabbit serum diluted 1:2000 in 2\% BSA in PBS. The serum was obtained from rabbits immunized with the $P$. zopfii genotype 2 type strain SAG 2012, as previously described by ROESLER et al. (2003). Biotinylated goat anti-rabbit IgG was used as a secondary antibody at a 1:200 dilution in 2\% BSA in PBS (30 minutes). For secondary antibody detection, the slides were incubated in avidin-biotin-peroxidase complex $(\mathrm{ABC})$ reagent for 30 minutes at room temperature. Subsequently, sections were incubated with 3,3'-diaminobenzidine (DAB) and counterstained with hematoxylin (Mayer). Immunohistochemistry demonstrated multifocal accumulation of numerous round to oval algal organisms measuring 5 to $10 \mu \mathrm{m}$ in diameter, which were located extracellularly or inside macrophages in the heart (Figure 1D) and cerebellum (Figure 1E) of the dog. P. zopfii genotype 2-specific restriction fragment length polymorphism (RFLP) was performed as described by RIBEIRO et al. (2009). Briefly, a specific 18S rDNA (405bp length) from DNA extracted from samples of heart and brain fragment was amplified and subsequently incubated with the endonuclease SmaI (ThermoFisher Scientific). Findings confirmed P. zopfii genotype 2 as the etiologic agent of the systemic infection in the dog (Figure 1F).

The pathomorphological findings, together with the results of immunohistochemical and RFLP analyses, revealed a systemic infection caused by $P$. zopfii genotype 2. Among dogs, Collies and Boxers tend to be more frequently affected (COOCK et al., 1987; STENNER et al., 2007). Clinical signs exhibited by the dog in this case occurred due to infection of the brain and were characterized by severe tetraparesis and vertical nystagmus. Neurological signs in this case were similar to those of previously published cases of canine CNS protothecosis (SALVADORI et al., 2008).

P. zopfii is the species most frequently affecting dogs (PRESSLER, 2012). Algae of the genus Prototheca are distributed in the environment, mainly in humid sites rich in organic matter, which allowed the propagation and perpetuation of the agent (CAMBOIM et al., 2010). The transmission pathway is not clearly established (PAL et al., 2014). In dogs, protothecosis occurs via traumatic algal infection or wound contamination. However, the oral route appears to be important in canines, as hemorrhagic colitis is a more frequent clinical manifestation in dogs (DILLBERGER et al., 1988), and the gastrointestinal form, which is characterized by colitis, is most commonly reported (STENNER et al., 2007). There is evidence that dissemination of the agent can occur through hematogenous and lymphatic routes from primary sites such as the colon (PRESSLER, 2012). Inhalation and cutaneous penetration, which cause primary lesions, can also lead to subsequent systemic infection (GINEL et al., 1997; STENNER et al., 2007). In this case, it was not possible to determine the portal of entry because the dog did not have intestinal and cutaneous lesions, and the eyes were not collected. Genotyping in canines has been described in a case in which infection by $P$. zopfii genotype 2 caused enteric signs in a dog (RIBEIRO et al., 2009). Regardless, predisposing factors to protothecosis have not been well established because the immune status of the patients has been evaluated in only a few cases (HOLLINGSWORTH, 2000).

Genotype 2 of $P$. zopfii has been established as a pathogenic agent in dogs, and virulence factors are being investigated (IRRGANG et al., 2015). Some authors have reported that the organism inhibits inflammatory cell migration and proliferation, which suggests that Prototheca spp. inhibit the local cellular response (PÉREZ et al., 1997). This was also observed in the present study, whereby a mild inflammatory infiltrate was observed in the affected tissues, along with large amounts of the organism. In this case, the canine was treated with corticoids, and this may have contributed to suppressing the inflammatory response.

The present report demonstrated that a diagnosis of protothecosis in canines, albeit rare, should be considered when the animal exhibits neurological signs. Genotypic characterization of P. zopfii strains in dogs can be important for understanding the epidemiology of the disease and for increasing knowledge of the most important genotypes affecting these animals.

\section{REFERENCES}

CAMBOIM, E.K.A. et al. Protothecosis: an emergent disease. Pesquisa Veterinária Brasileira, v.30, n.1, p.94-101, 2010. Available from: <http://www.scielo.br/pdf/pvb/v30n1/v30n1a15. pdf>. Accessed: Jan. 06, 2016.

CARNEIRO, F.P. et al. Prototecose cutânea: relato de caso. Revista da Sociedade Brasileira de Medicina Tropical, v.40, p.466-468, 2007. Available from: <http://www.scielo.br/pdf/rsbmt/v40n4/ a18v40n4.pdf>. Accessed: Jan. 07, 2016.

COOCK, J.R. et al. Disseminated protothecosis causing acute blindness and deafness in a dog. Journal American Veterinary Medical Association, v.184, p.1266-1272, 1984. Available from: $<$ http://www.ncbi.nlm.nih.gov/pubmed/6735845>. Accessed: Jan. 06, 2016. 
DILLBERGER, J.E. et al. Protothecosis in two cats. Journal American Veterinary Medical Association, v.192, p.15571559. 1988. Available from: <http://www.ncbi.nlm.nih.gov/ pubmed/3410772>. Accessed: Jan. 06, 2016.

GINEL, P.J. et al. Cutaneous protothecosis in a dog. Veterinary Record, v.140, p.651-653, 1997. Available from: <http://www. ncbi.nlm.nih.gov/pubmed/9226849>. Accessed: Jan. 06, 2016.

HOLLINGSWORTH, S.R. Canine protothecosis. Veterinary Clinics of North America: Small Animal Practice, v.30, p.10911101, 2000. Available from: <http:/www.ncbi.nlm.nih.gov/ pubmed/11033876>. Accessed: Jan. 06, 2016.

HOSAKA, S.; HOSAKA, M. A case report of canine protothecosis. Journal of Veterinary Medical Science, v.66, p.593-597, 2004. Available from: <http://www.ncbi.nlm.nih.gov/ pubmed/15187378>. Accessed: Jan. 06, 2016.

HUTH, N. et al. Prototheca zopfii Genotype 2-induced nasal dermatitis in a cat. Journal of Comparative Pathology, v.152, n.4, p.287-290, 2015. Available from: <http://www.sciencedirect. com/science/article/pii/S0021997515000328>. Accessed: Jan. 07, 2016. doi: 10.1016/j.jcpa.2015.02.001.

IRRGANG, A. et al. Well-known surface and extracellular antigens of pathogenic microorganisms among the immunodominant proteins of the infections microalgae Prototheca zopfii. Frontiers in Cellular and Infections Microbiology, v.5, n.67, p.1-10, 2015. Available from: <https://www.ncbi.nlm.nih.gov/pmc/articles/ PMC4586511/>. Accessed: May 21, 2017.

LASS-FLÖRL, C.; MAYR, A. Human protothecosis. Clinical Microbiology Reviews, v.20, n.2, p.230-242, 2007. Available from: $<$ http://cmr.asm.org/content/20/2/230.full >. Accessed: May 21, 2017.

MACARTNEY, L. et al. Cutaneous protothecosis in the dog: first confirmed case in Britain. Veterinary Record, v.123, p.494-496, 1988. Available from: <http:/www.ncbi.nlm.nih.gov/ pubmed/3201697>. Accessed: Jan. 07, 2016.

MACEDO, J.T.S.A. et al. Cutaneous and nasal protothecosis in a goat. Veterinary Pathology, v.45, n.3, p.352-354. 2008. Available from: <http://www.ncbi.nlm.nih.gov/pubmed/18487492>. doi: 10.1354/vp.45-3-352. Accessed: Jan. 07, 2016.

PAL, M. et al. Protothecosis: an emerging algal disease of humans and animals. International Journal of Life Science and Pharma Reviews, v.3, n.4, p.1-13, 2014. Available from: <http://www. ijlbpr.com $/$ index.php? $\mathrm{m}=$ content $\& \mathrm{c}=\mathrm{index} \& \mathrm{a}=$ show $\&$ catid $=125 \&$ $\mathrm{id}=337>$. Accessed: May. 21, 2017.

PEREZ, J. et al. Canine cutaneous Protothecosis: an immunohistochemical analysis of the inflammatory cellular infiltrate. Journal of Comparative Pathology, v.117, p.8389, 1997. Available from: <http://www.ncbi.nlm.nih.gov/ pubmed/9263846>. Accessed: Jan. 07, 2016.

PRESSLER, B.M. Fungal and algal diseases. In: GREENE, C.E. Infections disease in $\mathbf{d o g}$ and cat. 4.ed. Missouri: Saunders Elsevier, 2012. p.696-701

RIBEIRO, M.G.et al. Phenotypic and genotypic characterization of Prototheca zopfii in a dog with enteric signs. Research in Veterinary Science, v.87, n.3, p.479-481, 2009 Available from: $<$ http://www.ncbi.nlm.nih.gov/pubmed/19520405>. Accessed: Jan. 07, 2016. doi: 10.1016/j.rvsc.2009.04.015.

ROESLER, U. et al. Emended phenotypic characterization of Prototheca zopfii: a proposal for tree biotypes and standards for their identification. International Journal of Systematic and Evolutionary Microbiology, v.53, p.1195-1199, 2003. Available from: <http://www.ncbi.nlm.nih.gov/pubmed/12892149>. Accessed: Jan. 07, 2016. doi: 10.1099/ijs.0.02556-0.

SALVADORI, C. et al. Protothecal granulomatous meningoencephalitis in a dog. Journal of Small Animal Practice, v.49, p.531-535, 2008. Available from: <http://www.ncbi.nlm.nih. gov/pubmed/18631224>. doi: 10.1111/j.1748-5827.2008.00579.x. Accessed: Jan. 07, 2016.

SIQUEIRA, A.K. et al. Prototecose Protothecosis in companion animals and aspects of the disease in human. Ciência Rural, v.38, p.1794-1804, 2008. Available from: <http://www.scielo.br/ scielo.php?script $=$ sci_arttext\&pid $=$ S0103-84782008000600052>. Accessed: Jan. 07, 2016.

STENNER, V.J. et al. Protothecosis in 17 Australian dogs and a review of the canine literature. Medical Mycology, v.45, p.249-266, 2007. Available from: <http://www.ncbi.nlm.nih. gov/pubmed/17464846>. doi: 10.1080/13693780601187158. Accessed: Jan. 07, 2016.

TSUJI, H. et al. An isolate of Prototheca wickerhamii from systemic canine protothecosis. Veterinary Microbiology, v.118, n.3-4, p.305-311, 2006. Available from: < http://www.ncbi.nlm.nih. gov/pubmed/16987617>. Accessed: Aug. 07, 2016. doi: 10.1016/j. vetmic.2006.08.003. 